\title{
The Effect of Dividend Policy on Share Price Manufacturing Companies in Indonesia
}

\author{
Bahtiar Usman \\ Faculty of Economics and Business \\ Universitas Trisakti \\ Jakarta, Indonesia \\ bachtiar.usman@trisakti.ac.id
}

\author{
Henny Setyo Lestari \\ Faculty of Economics and Business \\ Universitas Trisakti \\ Jakarta, Indonesia \\ henny_setyo_lestari@trisakti.ac.id
}

\author{
Syofriza Sofyan \\ Faculty of Economics and Business \\ Universitas Trisakti \\ Jakarta, Indonesia syofriza@gmail.com
}

\begin{abstract}
The objective of the empirical study is to examine and analyze the impact of dividend policy on the share prices. The sample object used in this research are manufacturing companies listed on Indonesia Stock Exchange in the period 2014-2018. The independent variables are dividend per share, retention ratio, return on equity, dividend yield and earnings per share. The dependent variable is share prices of manufacture sector. The number of the samples in this research are 36 companies by using purposive sampling technique. Based on the results of panel data regression model indicates that dividend per share has a positive impact on share prices. Dividend yield has negative impact on share prices. Retention ratio, return on equity and earnings per share has insignificant impact on share prices. The results of this study are expected to be the reference for companies and investors to increase share prices.
\end{abstract}

Keywords: dividend per share, dividend yield, earnings per share, retention ratio, return on equity, share prices

\section{INTRODUCTION}

The capital market has an important role in economic progress that encourages capital formation and sustains the country's economic growth [1]. The capital market is a place to sell and buy long-term financial instruments including the stock and bond markets [2]. The magnitude of the role of the capital market in increasing the investment growth of a country is reflected by the increase in the number of investors listed on the capital market [3]. Shares are the proof of ownership after the investor has invested some money in the company [4].

According to research [5] argues that investors are advised to conduct an analysis of the determinants of stock prices to make optimal investment decisions. Research by [6] states that stock prices are a major factor that can help investors make investment decisions. The strength of supply

and demand in the capital market can cause fluctuations in stock prices [7].

Investors are very interested in stock investors because of two things, in the form of dividends and capital gains that investors expect to gain profits [1]. Dividends are distributed by companies to investors from the profits of the company. Capital gains are obtained by investors with a positive difference between the purchase price of shares and the selling price of shares [6]. Dividend payments provide information to investors that the company has a strong financial advantage. An increase in the dividend payout ratio signals to investors that a long-term increase in profits is expected by the company [1].

Determination of an appropriate dividend policy is an important decision for the company, because the flexibility to invest in future projects depends on the amount of dividends the company pays to investors. Important factors such as managerial environment and behavior, company profitability ratios, etc. are considered by companies in designing dividend policies [8]. Factors influencing the relationship between dividend policy and the company's stock price used in this study are dividend per share, retention ratio, return on equity, dividend yield, and earnings per share [1].

According to research by [9] dividend per share reflects how much dividends investors get from the company's shares owned. Research by Ohiaeri et.al (2019) states that investors prefer an increase in the amount of dividends previously distributed. Increased dividends obtained by investors will increase interest in investing and share prices will increase along with increased investor confidence and company value.

According to research [1] retention ratio is a company's profit that is not distributed to investors compared to the company's total net profit. [10] shows that the higher the company gets the greater profit the profits retained by the company to meet its internal needs. The allocation of profits to the internal needs of the company can reduce the distribution of dividends that are not preferred by investors because of a decrease in return on investment and a decline in share prices. Research [1] says that the effect of increasing retention ratio will reduce stock prices.

Research [5] states that return on equity is a profitability ratio that measures the ability of companies to use their own capital to generate profits for investors, the increase in stock prices is influenced by the high return on equity owned by the company. According to the research of [10] testing the effect of return on equity on stock prices shows that efficient management performance can utilize resources and provide a good return on investment. The return can attract investors to invest in shares and affect the company's stock price increase. 
Research by [11] states that dividend yield reflects how much the company distributes the amount of dividend compared to its share price. According to research [1] dividend yield is used to measure the return on investment in shares received by investors in one year. The higher amount of dividends paid will affect the company's good performance and increase investor motivation to buy company shares and increase share prices.

According to research [12] explains that earnings per share is the income earned by the company and is used to reflect the value of the company in determining stock prices. Research [1] examines the effect between earnings per share and stock prices, high earnings per share will increase profits earned by the company and create a positive image of the company towards investors in making investment decisions that can increase stock prices.

Based on previous research conducted by [1] tested the effect of dividend policy on the stock prices of companies listed on the Nigerian Stock Exchange (NSE) during the 2009-2017 period. Dividend policies in influencing stock prices include dividend yields, earnings per share, dividends per share, return on equity and retention ratio. Based on this description, researchers are interested in conducting research in Indonesia with the title The Effect of Dividend Policy on Share Prices in Manufacturing Companies listed on the Indonesia Stock Exchange.

\section{LITERATURE REVIEW}

\section{A. Share Price}

Stock Risk is proof of ownership when an investor makes an investment in a number of funds to the company [4]. According to [13] it is stated that shares issued by companies are one of the corporate funding decisions. Shares are traded on a country's Stock Exchange and have an important role in macroeconomic growth. Stock price efficiency is the most fundamental research on the Stock Exchange. shares can be information for investors determining investment in the company to make a profit an important factor that can have an influence in determining the company's stock price is dividend payment [1] Corporate dividend policy can affect stock prices [14]. Understanding the influence of various fundamental variables on stock prices can help investors in making profitable investment decisions [15].

\section{B. Dividend Policy}

Research by [1] shows that dividend policy is one of the main decisions of a company's financial management. Dividends are profits obtained by investors as a return on risk and investment that can be determined by several factors in a company. The decision to distribute dividends provides information about the company's future cash flowsand can reflect the company's value. According to [8] research, the company's perspective in choosing the right dividend policy is an important decision because the flexibility to invest in future projects depends on the amount of dividends distributed to investors. Important factors such as the managerial environment and the company's profitability ratio can be considered by companies in designing dividend policies. According to research [16] argues that dividend policy is an important decision for companies to compete in an environment of global competition. Investor opinion regarding dividend distribution is a source of income and reflects whether the company is liquid or not. On the other hand, some theories argue that dividends do not have a strong influence on predicting stock prices. There are several dividend policy theories regarding investor preferences in investing stocks that support the research of [1], namely agency theory, signaling theory and dividend relevance theories.

\section{Dividend per Share}

Dividend per share is a dividend announced by the company and must be paid based on the number of shares outstanding to investors. Dividend per share is measured by distributing dividend paid with outstanding ordinary shares [1]. According to research [17] dividend per share shows how much companies pay dividends each year relative to each share owned by investors. The higher the dividend per share, the more attractive the stock will be to investors. Research by [9] states that dividend per share is a component of company profits distributed to investors as an investment risk borne by the company. [18] analyzes the amount of dividends distributed to investors in accordance with dividend policies that apply to companies. A stable dividend policy has an important role in creating a healthy investment climate and investors' decision preferences in investing and creating increased company growth.

\section{Retention Ratio}

Retention ratio is the ratio of the company's profit that is not distributed to investors. Retention ratios are measured by subtracting one with a dividend payout ratio (Ohiaeri, et.al 2019). Retained earnings are the main source of funding for the company [19]. Companies with low dividend payouts can allocate profits to reinvest in business. Retained earnings by a company can affect the company's stock price, this influence attracts some researchers to analyze the behavior of stock price movements at various levels of company growth [20].

The company's long-term financial strategy is a dividend policy with respect to the decision to determine how much income should be retained for a company's investment compared to dividend payments to investors. The company is effectively needed to manage policies in attracting potential investors and increase the trading of company shares in the capital market [20]. According to [21], the retention ratio is used as a dividend policy in choosing company decisions between dividend distribution to investors or maintaining profits in the company. The company must maintain its profit if the return on investment to investors exceeds the cost of capital, and vice versa. Research [22] mentions the measurement of retention ratio by reducing total dividends from total earnings and divided by earnings per share.

Research by [11] shows that retention ratios have a positive effect on stock prices. The higher the retention ratio the higher the stock price. An increase in retained earnings will increase the share price because the company has a long- term investment plan and can increase future profits that will attract potential investors to buy the company's 
shares so that the share price will increase. According to research by [10] there is a negative influence between retention ratio and stock prices. The higher company profits will increase the profits retained by the company to meet its internal needs and reduce share prices. Investor interest will be reduced because the current dividend distribution is getting lower and lowering stock prices.

\section{E. Return on Equity}

Return on equity is a ratio that describes how efficiently a company manages the amount of equity that an investor has invested [10]. Information on return on equity is needed as an attraction for investors to invest their capital in the company. Increasing wealth obtained through returns on shares is the main goal of investing investors [12] Return on equity is expressed as a percentage of the calculation of profit after tax against stockholders' equity [23].

According to [23] shows the positive effect of return on equity on stock prices. An increase in return on equity will increase stock prices. The company's management performance will efficiently use funds sourced from investors' investment to the company and obtain a higher return on investment to investors so that it positively influences the rise in share prices. An increase in return on equity will be an attraction for investors to buy shares of the company because it will increase investor returns. Stock demand that exceeds the offer can put pressure on the stock price to increase. According to [24] there is a negative effect of return on equity on stock prices. An increase in return on equity will reduce stock prices. The company will allocate profits from the acquisition of return on equity to be reinvested and make the opportunity an attractive investment rather than sharing the profits as dividends. The distribution of low dividends will reduce investor interest in investing, thereby reducing share prices.

\section{F. Dividend Yield}

According to [25] dividend yield is a number of returns obtained by investors in the form of dividends which shows how much the company pays dividends each year relative to its share price. In line with research by [9], dividend yield is the result of stock investments that can be enjoyed by investors based on their equity and serves as an indicator in determining investment decisions. According to research [1] dividend yield is measured by dividing the dividend per share by the current price.

According to research by [26] there is a positive effect of dividend yield on stock prices. An increase in dividends set by a company's financial manager can attract the attention of potential investors in obtaining profits and increasing share prices. While the research of [27] shows that there is a negative influence between dividend yield on stock prices. A decrease in dividend yield can increase stock prices. Companies reduce the distribution of dividend yields to investors and allocate profits for investment and get more profits in the future and can share more profits with investors in the future, some investors like the distribution of investors in the future thereby increasing demand for company shares and increasing share prices.

\section{G. Earning per Share}

Earning per share is profit per unit in per common stock. The number of ordinary shares that have been bought by investors is referred to as common shares outstanding [28]. Earning per share is measured by dividing profit after tax by the number of issued ordinary shares [1]. Earnings per share is the ratio of profit after tax divided by the number of ordinary shares of the company per year. The higher earning per share, the greater the scope for higher levels of profit sharing as returns to investors and retained earnings to build company strength [9].

Research by [1] examined the positive effect between earnings per share and stock prices. The higher earning per share will be better for the company to reflect the company's future business prospects and higher investment returns for investors. According to research [29] shows the negative effect of earnings per share on stock prices. The share price decreases as earnings per share increase. These opposing influences can be found for a number of reasons: first, the microeconomic factors of the company, including the company's internal factors which are largely determined by the influence of the company's director. Its influence in the form of resignation from the board of directors can lead to a negative image of the company and doubts in the minds of the public about the company's financial stability which affects the decline in the company's stock price. Second, macroeconomic factors. Investors in buying shares in the capital market are not based on earnings per share recorded in the company. The company's external factors that affect stock price movements such as interest rates, inflation, deflation, and changes in the country's economic policies.

\section{METHOD}

The research design used in this study is hypothesis testing, namely testing the effect of independent variables namely dividend per share, retention ratio, return on equity, dividend yield, and earnings per share on the dependent variable, namely share price. The analytical method used in this study is multiple linear regression. The unit of analysis used in this study is manufacturing companies listed on the Indonesia Stock Exchange during the 2014-2018 period. The analytical method used is panel data regression with a measurement tool used to process data, the Eviews 9.0 software. 
TABLE I. VARIABLES AND MEASUREMENTS

\begin{tabular}{|c|c|c|c|}
\hline Variables & Measurements & $\begin{array}{l}\text { Expected } \\
\text { Sign }\end{array}$ & Literature \\
\hline $\begin{array}{c}\text { Independent } \\
\text { Variables }\end{array}$ & & & \multirow{8}{*}{ [1] } \\
\hline $\begin{array}{l}\text { Dividend } \\
\text { per Share }\end{array}$ & $\begin{array}{l}\text { Dividend Paid / } \\
\text { Outstanding } \\
\text { Ordinary Share }\end{array}$ & $(+)$ & \\
\hline $\begin{array}{l}\text { Retention } \\
\text { Ratio }\end{array}$ & $\begin{array}{l}1-\text { Dividend } \\
\text { Payout ratio }\end{array}$ & & \\
\hline $\begin{array}{l}\text { Return on } \\
\text { Equity }\end{array}$ & $\begin{array}{l}\text { Profit After Tax / } \\
\text { Shareholder,s } \\
\text { Equity }\end{array}$ & $(+)$ & \\
\hline $\begin{array}{l}\text { Dividend } \\
\text { Yield }\end{array}$ & $\begin{array}{l}\text { Dividend per } \\
\text { Share / Currrent } \\
\text { Price }\end{array}$ & $(-)$ & \\
\hline $\begin{array}{l}\text { Earning per } \\
\text { Share }\end{array}$ & $\begin{array}{l}\text { Profit After Tax / } \\
\text { Oustanding } \\
\text { Ordinary Share }\end{array}$ & $(+)$ & \\
\hline \multicolumn{3}{|l|}{$\begin{array}{l}\text { Dependent } \\
\text { Variables }\end{array}$} & \\
\hline Share Price & $\begin{array}{l}\text { Closing Share } \\
\text { Price as at } 31^{\text {st }} \\
\text { December for the } \\
\text { years }\end{array}$ & & \\
\hline
\end{tabular}

The data testing method used in this study is panel data regression. Available data will be measured and tested using E-views 9.0 software. Data analysis method in this research uses multiple regression analysis. This analysis aims to examine and analyze the influence of independent variables namely dividend per share, retention ratio, return on equity, dividend yield and earnings per share on the dependent variable, namely the stock price of manufacturing companies listed on the Indonesia Stock Exchange in 2014 - 2018. Model Regression in this study is as follows:

$$
\mathrm{SP}_{\mathrm{it}}=\beta_{0}+\beta_{1} \mathrm{DPS}_{\mathrm{it}}+\beta_{2} \mathrm{RR}_{\mathrm{it}}+\beta_{2} \mathrm{ROE}_{\mathrm{it}}+\beta_{3} \mathrm{DY}_{\mathrm{it}}+\beta_{4} \mathrm{EPS}_{\mathrm{i}}+\varepsilon_{\mathrm{it}}
$$

$\mathrm{SP}_{i t} \quad=$ Share Price

$\mathrm{DPS}_{i t}=$ Dividend per Share

$\mathrm{RR}_{i t} \quad=$ Retention Ratio

$\mathrm{ROE}_{i t} \quad=$ Return on Equity

DY $_{i t}=$ Dividend Yield

EPS $_{i t}=$ Earnings per Share

E = Error

IV. RESULTS AND DISCUSSION

TABLE II. DESCRIPTIVE STATISTICS

\begin{tabular}{|c|c|c|c|c|c|}
\hline Variable & Obs & Mean & Max & Min & Std. Dev \\
\hline SP & 180 & 6054.950 & 74873.00 & 120.0000 & 11190.03 \\
\hline DPS & 180 & 347.7931 & 12499.59 & 2.743400 & 1162.551 \\
\hline RR & 180 & 0.910794 & 65.28866 & 8.136616 & 4.903551 \\
\hline ROA & 180 & 0.223103 & 2.254461 & 0.004415 & 0.306733 \\
\hline DY & 180 & 0.058461 & 1.689134 & 0.000593 & 0.170305 \\
\hline EPS & 180 & 549.9470 & 17989.77 & 36.09908 & 1595.699 \\
\hline
\end{tabular}

T test aims to test the regression coefficients of each independent variable and control variables on the dependent variable. And to find out how much influence between dividend per share, retention ratio, return on equity, dividend yield and earnings per share on share prices in manufacturing companies. If $\mathrm{sig}$ of $\mathrm{t}<0.05$ then $\mathrm{H} 0$ is rejected, meaning that the independent variable has an influence on the dependent variable and vice versa. The following shows the results of the $t$ test of each variable used in the study:

\section{TABLE III. T-TEST RESULT}

\begin{tabular}{|l|c|c|}
\hline \multicolumn{1}{|c|}{ Variables } & Coefficient & Prob. \\
\hline Dividend Per Share & -1.067095 & 0.0004 \\
\hline Retention Ratio & -0.006478 & 0.4897 \\
\hline Return On Equity & -0.028793 & 0.7186 \\
\hline Dividend Yield & -1.052988 & 0.0000 \\
\hline Earning Per Share & 0.000119 & 0.0000 \\
\hline
\end{tabular}

Based on the results of hypothesis testing using the results of the $t$ test, it can be interpreted the effect of each independent variable and the control variable on the dependent variable as follows:

The regression test results of this research indicate that there is a negative influence between dividend per share on stock prices. The results of this study are not in line with research conducted by [1] which states that there is a positive influence between dividend per share on stock prices, declining dividend per share will reduce share prices. This research is supported by [30] showing that dividend per share has a negative influence on stock prices. The results showed an increase in dividend per share could reduce share prices compared to last year. Investors expect an increase in dividend per share that is shared and increase share prices, but this research results in an increase in dividend per share research that can reduce share prices compared to last year. [15] supports the negative effect between dividend per share and share price, a decrease in dividend per share will increase share prices. Dividend distribution from the company side is cash outflow which reduces the company's cash, therefore the opportunity to invest is reduced. The investment decision becomes the company's management policy in using the profits obtained and reducing the distribution of dividends to investors. The company's investment will increase the profits obtained and it is assumed by the community as a profitable company and able to pay dividends that will attract potential investors so that the stock price increases.

This research indicates that there is no significant effect between retention ratio on stock prices. The results of this study are in line with research conducted by [1] which states there is no influence between retention ratio on stock prices. According to [8] who support this research said there is no effect between retention ratio on stock prices. This study is supported by [19] which states that there is no effect of retention ratio on stock prices, the proportion of company dividend policy in the form of a policy between the distribution of profits between dividends and retained earnings does not affect the wealth of investors in investing in shares of the company. Dividend policy is considered irrelevant because it cannot affect the value of the company explained by the opinion of [31]. Dividend policy is irrelevant to investor prosperity because the distribution of dividends is a deduction from retained earnings that the company expects for investment, so the company will seek 
new funds to meet the needs of these funds. The increase in dividend distribution will be followed by a decline in share prices due to the activities of companies that sell new shares or issue debt. Retained earnings for investment do not affect shareholder wealth and do not affect the movement of stock prices.

There is no influence between return on equity on stock prices in manufacturing companies listed on the Indonesia Stock Exchange from the regregression test results. The results of this study are in line with research conducted by [1] which states there is no influence between return on equity on stock prices. In line with the results of the research by [32] which showed no influence between return on equity and stock prices. That is because stock prices are more influenced by factors other than the company's fundamentals. Stock prices are controlled by market rumors caused by a lack of investor knowledge about the company's fundamentals.

Research by [10] supports this study with the results of the study that there is no influence between return on equity on share price. The ineffectiveness of return on equity to stock prices shows that some investors are not interested in earning long-term profits in the form of dividends, but some investors prefer short-term profits, namely capital gains so that in making stock purchase decisions, the company does not consider purchasing return on equity but follows trends in the market and negative sentiment for investors about the company's prospects related to efficiency in using their own capital to generate profits.

This research indicates that there is a negative and significant effect between dividends per share on stock prices in manufacturing companies listed on the Indonesia Stock Exchange. The results of this study are not in line with research conducted by [1] which states that there is a positive influence between dividends per share on stock prices. This research is supported by [27] who show the negative effect between dividend yield on stock prices. A decrease in dividend yield can increase stock prices. Companies reduce the distribution of dividend yields to investors and allocate profits for investment and get more profits in the future and can share more profits with investors in the future, some investors like the distribution of investors in the future thereby increasing demand for company shares and increasing share prices [21] states that there is a negative influence between dividend yield on stock prices. Increased company earnings will be allocated for high debt repayments so that future expenditure decreases as interest from these loans and can be an investor analysis because lower costs can increase earnings in the future and attract many investors to pressure stock prices to increase.

The regression test results of this study indicate that there is a positive effect between earnings per share on stock prices on manufacturing companies listed on the Indonesia Stock Exchange. The results of this study are not in line with the results of research conducted by [1] which states there is no influence between earnings per share on stock prices. This research is supported by [29] which shows earnings per share have a positive effect on stock prices. Increased earnings per share will increase share prices. Companies get high earning per share can increase share prices. High stock prices create a positive image of the company's products in the minds of consumers. This positive image can lead to greater demand and an increase in sales will get higher income and attract potential investors to buy company shares. Declining earnings per share will depress stock prices because it can reduce consumer confidence and corporate sales result in lower earnings per share. [13] research supports a positive influence between earnings per share on stock prices. Investors use information on the movement of company stock prices to make decisions about buying and selling shares, high stock prices can be influenced by the acquisition of companies with high earnings per share. Companies consider earnings per share to maintain the company's image and customer satisfaction with the products sold by the company and increase share prices.

\section{CONCLUSION}

The conclusions from the results of the research that can be drawn are as follows: dividend per share has a negative effect while dividend yield also negatively affect share price. Earning per share has a positive effect on share price. While retention ratio and return on equity have no effect on share price. Increasing company profits in the long run and high dividend distribution can increase the interest of potential investors and the higher share prices. For further research is expected to add variable that effect the share price, as conducted in research [33], namely book value per share.

\section{REFERENCES}

[1] N. Ohiaeri, F. V, Akinbowale, and B. I, Ogumeru, "The Impact Of Dividend Policy On The Share Price Of Quoted Companies In Nigerian Stock Exchange.," Int. J. Econ. Manag. Stud., vol. 6, no. 8, pp. 145-156, 2019.

[2] D. Chavan, M. Upadhyaya, A. A. Alazzawi, and H.

M. EL-Shishini, "An empirical study on investors investment initiatives in Indian capital market," Int.

J. Civ. Eng. Technol., vol. 8, no. 10, pp. 213-223, 2017.

[3] B. K. Vaziri and A. Adham, "The Effects of Expected Stock Returns and Stock Prices Volatility on Corporate Operational Risk (Tehran Stock Exchange)," Glob. J. Manag. Bus. Res. Account. Audit., vol. 15, no. 3, pp. 27-32, 2015.

[4] M. A. Almumani, "Determinants of Equity Share Prices of the Listed Banks in Amman Stock Exchange: Quantitative Approach," Int. J. Bus. Soc. Sci., vol. 5, no. 1, pp. 91-104, 2014.

[5] T. Sharif, H. Purohit, and R. Pillai, "Analysis of Factors Affecting Share Prices: The Case of Bahrain Stock Exchange," Int. J. Econ. Financ., vol. 7, no. 3, pp. 207-216, 2015 .

[6] S. B. Duke, N. I. Dominic, and Nkamare, "Impact of Dividend Policy on Share Price Valuation in 
Nigerian Banks," Arch. Bus. Res., vol. 3, no. 1, pp. 156-170, 2015

[7] Y. R. Bhattarai, "Determinants of Share Price of Nepalese Commercial Banks," Econ. J. Dev. Issues, vol. 17, no. 1, pp 187-198, 2014.

[8] K. I. Khan, "Effect of Dividends on Stock Prices- A Case of Chemical and Pharmaceutical Industry of Pakistan," Management, vol. 2, no. 5, pp. 141-148, 2012.

[9] N. Malhotra and K. Tandon, "Determinants of Stock Prices: Empirical Evidence from NSE 100 Companies," Int. J. Res. Manag. Technol., vol. 3, no. 3, pp. 2249-9563, 2013.

[10] A. I. Hunjra, M. Ijaz, M. Shahzad, M. I. Chani, S. ul Hassan, and U. Mustafa, "Impact of Dividend Policy, Earning per Share, Return on Equity, Profit after Tax on Stock Prices," Int. J. Econ. Empir. Res., vol. 2, no. 3, pp. 109-115, 2014.

[11] L. H. Warrad, "The Effect of Market Valuation Measures on Stock Price: An Empirical Investigation on Jordanian Banks," Int. J. Bus. Soc. Sci., vol. 8, no. 3, pp. 67-74, 2017.

[12] N. Emamgholipour, M Pouraghajan, A., Ail and Y. Tabari, "The Effects of Performance Evaluation Market Ratios on the Stock Return : Evidence from the Tehran Stock Exchange," Int. Res. J. Appl. Basic Sci., vol. 4, no. 3, pp. 696-703, 2013.

[13] A. Niresh and T. Velnampy, "Firm size and profitability: A study of listed manufacturing firms in Sri Lanka," Int. J. Bus. Manag., vol. 9, no. 4, pp. 57-64, 2014.

[14] W. A. Adesola and A. E. Okwong, "an Empirical Study of Dividend Policy of Quoted Companies in Nigeria," Glob. J. Soc. Sci., vol. 8, no. 1, pp. 85-101, 2009.

[15] P. Srinivasan, "Determinants of Equity Share Prices in India : A Panel Data Approach," Rom. Econ. J., vol. 46, no. 6, pp. 205228, 2012.

[16] D. A. OGOLO, "The effect of dividend policy on share prices of multinational and local Companies listed at the Nairobi Securities Exchange," SCHOOL OF BUSINESS, UNIVERSITY OF NAIROBI, 2011.

[17] S. Haque and M. Faruquee, "Impact of Fundamental Factors on Stock Price: A Case Based Approach on Pharmaceutical Companies Listed with Dhaka Stock Exchange," Int. J. Bus. Manag. Invent., vol. 2, no. 9, pp. 34-41, 2013.

[18] S. Sharma, "Determinants of Equity Share Prices in India," $J$. Arts, Sci. Commer., vol. 2, no. 4, 2011.

[19] U. G. V. D. D. Gunarathne, W. A. N. Priyadarshanie, and S. M. R. K. Samarakoon, "Impact of dividend policy on stock price volatility and market value of the firm: Evidence from Sri Lankan manufacturing companies," International Conference on Business Management, pp. 219-225, 2016.

[20] S. Munir, M. I. Kharal, and S. A. R. Abidi, "Impact of Cash Dividends and Retained Earnings on Stock Price A Comparative Study of High and Low Growth of Firms," Res. J. Financ. Account., vol. 8, no. 11, pp. 51-57, 2017.

[21] N. P. Singh and A. Tandon, "The Effect of Dividend Policy on Stock Price: Evidence from the Indian Market," Asia-Pacific J. Manag. Res. Innov., vol. 15, no. 1-2, pp. 7-15, 2019.

[22] B. B. Majanga, "The Dividend Effect on Stock Price- An Empirical Analysis of Malawi Listed Companies," Account. Financ. Res., vol. 4, no. 3, pp. 99-105, 2015.

[23] A. Al-Masum, "Dividend Policy And Its Impact On Stock Price - A Study On Commercial Banks Listed In Dhaka Stock Exchange," Glob. Discl. Econ. Bus., vol. 3, no. 1, pp. 9-20, 2014.

[24] B. Jitmaneeroj, "The impact of dividend policy on priceearnings ratio: The role of conditional and nonlinear relationship," Rev. Account. Financ., vol. 16, no. 1, pp. 125140, 2017.

[25] F. Ruhani, T. Salha, T. Ahmad, and M. R. Quddus, "Effects of Financial Market Variables on Stock Prices: A Review of the Literature," J. Mod. Account. Audit., vol. 14, no. 11, pp. 597610, 2018.

[26] S. T. Enow and P. Brijlal, "Determinants of Share Prices: the Case of Listed Firms on Johannesburg Stock Exchange," $J$. Account. Manag., vol. 6, no. 1,pp. 85-92, 2016.

[27] F. O. Aribaba, O. L. Ahmodu, S. O. Ogbeide, and J. O. Olaleye, "Dividend policy and share price changes in the stock market: evidence from nigeria," J. Bus. Organ. Dev., vol. 9, no. December, pp. 30-47, 2017.

[28] N. Jain and K. Bajaj, "Impact of Earnings per Share on Market Price of Share with Special Reference to Selected Companies Listed on NSE," Int. J. Eng. Manag. Res., vol. 7, no. 3, pp. 1-9, 2017.

[29] M. R. Islam, T. R. Khan, T. T. Choudhury, A. M. Adnan, and 1 Senior Lecturer, "How Earning Per Share (EPS) Affects on Share Price and Firm Value," Eur. J. Bus. Manag., vol. 6, no. 17, pp. 2222-2839, 2014.

[30] N. Nautiyal and P. C. Kavidayal, "Analysis of Institutional Factors Affecting Share Prices: The Case of National Stock Exchange," Glob. Bus. Manag. Res., vol. 19, no. 3, pp. 1-15, 2018.

[31] M. H. Miller and F. Modigliani, "Dividend policy, growth, and the valuation of shares," J. Bus., vol. 34 , no. 4, pp. 411-433, 1961.

[32] R. Haque, a T. M. Jahiruddin, and F. Mishu, "Dividend Policy and Share Price Volatility: A Study on Dhaka Stock Exchange," Aust. Acad. Account. Financ. Rev., vol. 4, no. 3, pp. 89-99, 2018.

[33] S. Sharma, "Determinants of Equity Share Prices in India," J. Arts, Sci. Commer., vol. 2, no. 4, pp. 51-60, 2011. 